Volume 9 No.2, March - April 2020

International Journal of Advanced Trends in Computer Science and Engineering

Available Online at http://www.warse.org/IJATCSE/static/pdf/file/ijatcse148922020.pdf

https://doi.org/10.30534/ijatcse/2020/148922020

\title{
Machine learning Structural Equation Modeling Algorithm to Measure Performance
}

\author{
Dr.A.M.Mahaboob Basha ${ }^{1}$, Dr.P.Chenchu Reddy ${ }^{2}$, Dr.G.Radha Krishna Murthy ${ }^{3}$, B.Ankaiah ${ }^{4}$, \\ U.Dadakalandar ${ }^{5}$ \\ ${ }^{1}$ Department of Management Studies, Audisankara College of Engineering \& Technology, Gudur, \\ drbasha3@gmail.com \\ ${ }^{2}$ Department of Management Studies, Vikrama Simhapuri University, Nellore, India. drpcreddy9@gmail.com \\ ${ }^{3} \mathrm{H} \& S$ Department, Sri Venkateswara College of Engineering, Nellore, India. ghatty.radhi@ gmail.com \\ ${ }^{4}$ Department of Management Studies, Yogi Vemana University, Kadapa, India. ankaiah.mba@ gmail.com \\ ${ }^{5}$ Department of Tourism Management, Vikrama Simhapuri University, India. kalandar.mba@gmail.com
}

\begin{abstract}
Aim of this paper is to investigate the mediating and moderating role of employee performance and ethical Dilemma on organizational performance. In contemporary business practical implementation of ethical values plays a crucial role. Lacking of ethicality in the implementation of ethical concepts creates organizational deficiency. The implementation of ethical values can be seen in all areas like: training and development, performance appraisal, compensation and career planning which creates employee performance leads to organizational performance. Design/methodology/approach- The current research basically runs with secondary data followed by primarily data, using structured closed ended questionnaire to collect opinion from various respondents in the study area of transport sector. The data collected from 200 sample respondents. The questionnaire validated through pilot study and loaded factors validated through confirmatory factor analysis and model through goodness of fit index. The results of the hierarchical regression of complex mediated moderation reveal the significant positive relationship between HRM practices and employee performance leads to organizational performance. The ethical dilemma interacted with employee performance in such a manner that HRM practices with following ethical values will creates high organizational performance as employees fee that, organization following organizational code of conduct and ethics, which creates high organizational performance. The present research done on the basis of available literature in India and western context, the research has practical implications on MNC's where Human resource will be treated as assets of the organization. The specialty of the study is, the outcome of the research can be generalized to anywhere under any circumstances and situations. The study will create new insights to the readers which is unknown in previous research studies.
\end{abstract}

Key Words: Ethical Dilemma, Ethics, Moderation, Mediation, Human values, values, etc..

\section{INTRODUCTION}

The ethical foundation is essential in every organization for long-run survival. The efficiency and efficacy of the organization will depends on the ethical practices which are being followed by the organizations. It is evident from the literature that, the organizational performance is being depends up on various aspects like: appraisal, training, career development, employee compensations are directly linked with the organizational performance. In this context, following of ethical values plays a significant role, it is evident from many literatures that, lacking of ethical values while performing many aspects in the organization will leads to employee dissatisfaction consequently organizational performance gradually will decrease. In the present research researcher is trying to consider ethical values as a moderator which moderates, employee performance followed by organizational performance in the organization.

\section{REVIEW OF LITERATURE}

Author conducted a research work in the area of HRD in milk industry. The outcome of the research evident that, personnel development is a continuous process and management need to come-up with various HRD development strategies which impact on organizational prosperity. The team work, employee-employer relationship, organizational culture will pays a significant role in the process of human resource development in the organization [1].have conducted a research study in IT industry, the high performance IT industries will be influenced by HRD practices. In the present study, analyzed the data with the help of various tools like: ANOVA followed by correlation. In all aspects the outcome of the research reveals that, HRD practices plays a significant role for the development of an 
organization [2].Human resource is the important assets of an organization. In the perspective of H-Manager, the personnel in the company need to be treated as important asset in the organization. The concern people need to concentrate on skill enhancement, job-satisfaction, appraising the performance of employees which makes to run our organization towards to reach the mission of the organization [3].HRD practices will pay a significant role in overall in overall development of the organization. The technology driven concepts makes an organization more effective in the implementation process of human resource development practices [4].done research with the help of primary data sources in HRD aspects, as per the innovative HRD practices will impact more on the development of human resource management practices in banking industry. It has been found that convergence of practices of new and innovative HR areas will benefit the banks to become more competitive [5].Human resource development practices are essential to sharpen their capabilities which impact on organizational productivity and development. It is mainly impact on to improve individual efficiency through training and performance appraisal.[6].

The strategic change in the organizational development can bring through effective HRM practices and also witnessed that, the implementation of IT practices in HR plays a significant role which will impact on organizational productivity [7].Conducted a research study, the outcome of the research revealed that, there are certain HRM practices like: training, compensation, performance appraisal, staffing, employee grievances and empowerment have shown significant positive relationship with the organizational performance [8].Claimed that, the high involvement of HRM practices in relationship between organizational performances in Oman. The high involvement of HRM practices will show the significant positive relationship with the organizational performance [9].Observed HRM practices and their impact on company performance in Chinese enterprises where they used 465 samples, with (6) practices, among these, employment security, service performance and job description will enhance employee contributions to the development of organization.[10].the present study shows that, the ethical dilemma will moderate the relationship among various factors (Training, performance, career, compensation and employee performance) on organizational performance [11]. Argued that, training and development will enhance ability, skills and knowledge which facilitate to drive the organization towards attainment of organizational goals. Compensation refers to economic payments and monitory incentives provided to the employees [12]. Performance appraisal pays a countless, significant role for prosperity of the organization. However, it is also observed that, performance appraisal is seeing as continuous process [13].performance appraisal is a key to provide incentive to the talented personnel to be satisfied with the organization. Previous research studies witnessed that, there is a significant positive relationship between promotion opportunity and organizational performance [14]. The outcome of the research evident that, the late coming to the organization may be due to many factors like: employee performance appraisal, employee compensation and working conditions of the institution. The late coming to the organization surely will impact on the productivity of the organization [15].The outcome of the research reveals that there are various factors which impact on the performance of employees which have shown $96.77 \%$ of accuracy. It is also proved that, the number of instances which have given the positive results also. The Naïve Base machine learning algorithm has given accurate results while measuring the performance of employees [16].Conducted a research study conclude that, enhancing employee creativity is essential which will happen through knowledge management process in the organization. The knowledge management department will store the tacit knowledge of employees in the organization [17].

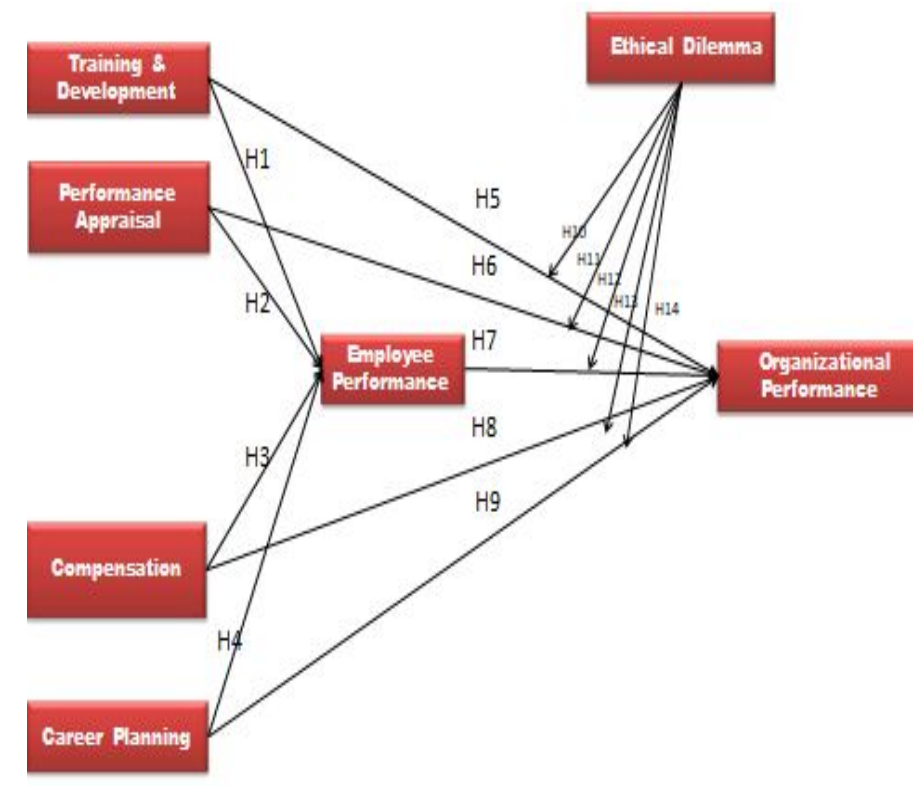

Figure1: Conceptual Model: Organizational Performance (Vs) Ethical values

\section{DATA ANALYSIS AND RESULTS}

Training and Development: Training and development will enhance the capabilities of individuals, which impact on organizational performance. Training plays a significant role for taking an organization in forward direction towards organizational attainments. In fact, employee performance is strongly associated with the training facilities provided by the organization. An hypothesis was developed based on the model was

$H_{1:}$ There is a significant positive relationship between employee training and employee performance with respect to organizational performance.

Performance Appraisal: There should be ethical performance appraisal in the organization. Ethical performance appraisal makes an employee more committed and dedicated towards organizational accomplishments. 
There should not be any halo effect or leniency effect on performance appraisal. Now days in the corporate culture, the ethicality is lacking while appraising the performance of an employee. In fact, the employee performance is strongly associated with the organizational performance. Based on from the above concept, an hypothesis was developed:

$H_{2}$ : There is a significant positive relationship between appraisal and performance with respect to organizational performance.

Compensation: The compensation, what we pay to the employee plays a significant role, compensation has to be paid on the basis of norms of the industry. But, in the corporate world, it is a very big question that, whether organizations are paying compensation as per the norms or not. Most of the employees are getting dissatisfied regarding pay received from the organization. Based on this an hypothesis was developed

$H_{3:}$ There is a significant positive relationship between appraisal and performance with respect to organizational performance.

Career Planning and Development: Employee career development concepts are essential for every organization. Every organization should pan for employee career development programs for their future development. It is lacking very much in now a days. Hypothesis was developed based on the evidencedls drawn from the analysis.

$\mathrm{H}_{4}$ : There is a significant positive relationship between career development and employee performance with respect to organizational performance.

Ethical Dilemma as a Moderator

The ethical dilemma interact with the training and development, where the institution follows ethical values while conducting training programs to the employees leads to high employee job satisfaction followed by high organizational performance. In the same manner, ethical dilemma interact with the performance appraisal in such a manner, that the good ethical performance appraisal practices will enhance the employee job satisfaction followed by high organizational performance can be expected. In the same manner, ethical dilemma interacts with employee compensation, where ethical compensation will create high employee job satisfaction followed by high organizational performance. At last, even the career development programs also plays a significant role in such a manner that, the better practices of employee career development programs will enhance employee job satisfaction followed by organizational performance.

$H_{5}$ : Ethical Dilemma moderates the relationship between Training and organizational performance in such that at following Ethicality in Training is associated with higher level of organizational performance.

$H_{6}$ : Ethical Dilemma moderates the relationship between employee Performance appraisal and organizational performance in such that at following Ethicality in Performance appraisal is associated with higher level of organizational performance.
$H_{7}$ : Ethical Dilemma moderates the relationship between employee compensation and organizational performance in such that at following Ethicality in employee compensation is associated with higher level of organizational performance.

$H_{8}$ : Ethical Dilemma moderates the relationship between employee career development and organizational performance in such that at following Ethicality in employee career development is associated with higher level of organizational performance

Table1: Mean-Standard Deviation- Correlation Matrix

\begin{tabular}{lcccccccc}
\hline Factors & M & SD & OP & ED & TD & EJS & PA & EC \\
\hline OP & 4.2 & .610 & 1 & & & & & \\
ED & 4.0 & .742 & $.297^{* *}$ & 1 & & & & \\
TD & 3.8 & .966 & $.294^{* *}$ & $.362^{*}$ & 1 & & & \\
EJS & 4.0 & .891 & $.256^{* *}$ & $.300^{*}$ & $.54^{*}$ & 1 & & \\
PA & 3.9 & .733 & .047 & $.097^{*}$ & .172 & $.253^{* *}$ & 1 & \\
EC & 4.1 & .831 & $.753^{* *}$ & $.387^{*}$ & $.24^{*}$ & $.229^{* *}$ & .045 & 1 \\
\hline
\end{tabular}

Confirmatory Factor Analysis:-

The training and development factor contains four indicators with 0.863 reliability[19] followed by standardized loadings are satisfied the standard measurement of reliability Nunnally [18] has given an optimum value of factors loadings that "trainer commitment(0.706)", "trainer communication (0.855)", "trainer approach towards employees (0.886)", "treatment (0.686)". The average variance extracted (AVE) value is 0.6213 . The discriminant validity measurement is 0.778. The performance appraisal factor contains four indicators with 0.806 reliability followed by standardized loadings "leniency in judgment (0.665)", " differ evaluation (0.807)", " personal prejudice (0.797)", " uniform evaluation criteria (0.591)". The average variance extracted (AVE) value is 0.5195 . the discriminant validity measurement is 0.721.The organizational performance factor contains four indicators with 0.962 reliability followed by standardized loadings are "good working conditions (0.943)", "employee performance (0.965)", " employee satisfaction (0.934)", " productivity $(0.873) "$. The average variance extracted (AVE) value is 0.8637 . The discriminant validity measurement is 0.929. The career planning and development factor contains four indicators with 0.804 reliability followed by standardized loadings are "counseling for future development $(0.741)$ ", "taking monitory care for future. (0.899)"," advanced skill enhancement (0.743)", " creating ladders for future $(0.461)$ ". The average variance extracted (AVE) value is 0.5305 . the discriminant validity measurement is 0.728 . The ethical dilemma factor contains four indicators with 0.844 reliability followed by standardized loadings are " organisational ethics (0.68)", " code of conduct $(0.791) "$ ", employee aspects $(0.875) ", "$ relational aspects $(0.691) "$. The average variance extracted 
(AVE) value is 0.5828. The discriminant validity measurement is 0.763 . The employee compensations factor contains four indicators with 0.901 reliability followed by standardized loadings are "pay in regular intervals (0.788)", "inequality in payment $(0.888)$ ", " inequality in payment as per norms $(0.885) "$ ", "pay as per performance $(0.783) "$. The average variance extracted (AVE) value is 0.2985 and the discriminant validity measurement is 0.546 .

Confirmatory Factor Analysis:-The above table elucidates the confirmatory factor analysis (CFA) outcomes. The sex-factor model fitted the data fine (chi-square $=729.605$; $\mathrm{df}=237$ have shown well [20] the [RMSEA $]=0.060$; RMR $=.031$; In fact, to test the validity of discriminant analysis, the famous authors [24] and [25] suggested the techniques to conduct the analysis. In this study, the variance-extracted observed for all the variables exceeded the recommended level of 0.50 Fornell and Larcker and also exceeded the squared correlation between the variables. Comparative fit index $[\mathrm{CFI}]=.945 ; \mathrm{TLI}=.936 ; \mathrm{GFI}=.907, \mathrm{AGFI}=.882$. The CFI for the six-factor model proves 0.90 and the RMSEA was 0.060. RMSEA of less than 0.08, in general, provides a good fit for the data which includes a model [21]. The comparative fit index (CFI>0.90) gives good fit of the model [22]. This goodness-of statistics for the six-factor model renders evidence of construct distinctiveness for training and development, performance appraisal, employee compensation, ethical dilemma, Organizational performance and career planning and development. The AGFI was 0.882 , the recommended criteria value is 0.80 [23]. The variance-extracted for training and development was 0.308 and performance appraisal 0.511 and career planning and development 0.312 , employee compensation 0.503 and ethical dilemma 0.301 have shown significant relationship among the variables.

Table 2: Results of Confirmatory Factor Analysis and Measurement Properties

\begin{tabular}{|c|c|c|c|c|c|c|}
\hline Factors & Alpha & $\begin{array}{l}\text { Standardiz } \\
\text { ed } \\
\text { loadings } \\
\left(\lambda_{y i}\right)\end{array}$ & $\begin{array}{c}\text { Composi } \\
\text { te } \\
\text { Reliabil } \\
\text { ity } \\
\left(\lambda^{2}{ }^{2}\right)\end{array}$ & $\begin{array}{c}\text { Varianc } \\
e \\
\left(\operatorname{Var}\left(\varepsilon_{i}\right.\right. \\
))\end{array}$ & $\begin{array}{c}\text { Average } \\
\text { Variance-extra } \\
\text { cted estimate } \\
=\sum \\
\left(\lambda_{y i}^{2}\right) /\left(\left(\lambda^{2}{ }_{y i}\right)+\right. \\
\left(\operatorname{Var}\left(\varepsilon_{i}\right)\right)\end{array}$ & $\begin{array}{l}\text { Discriminant Validity } \\
= \\
\sqrt{2(\lambda 2 y i) /(\lambda 2 y i)+(\operatorname{Var}(i}\end{array}$ \\
\hline \multicolumn{7}{|c|}{ Performance Appraisal } \\
\hline Trainer Commitment & \multirow{4}{*}{0.863} & 0.706 & 0.4984 & 0.5016 & \multirow{4}{*}{0.6213} & \multirow{4}{*}{0.788} \\
\hline $\begin{array}{l}\text { Trainer } \\
\text { Communication }\end{array}$ & & 0.855 & 0.7310 & 0.2690 & & \\
\hline $\begin{array}{l}\text { Trainer Approach } \\
\text { towards employees }\end{array}$ & & 0.886 & 0.7850 & 0.2150 & & \\
\hline $\begin{array}{l}\text { Trainers } \\
\text { Treatment/Behaviour }\end{array}$ & & 0.686 & 0.4706 & 0.5294 & & \\
\hline \multicolumn{7}{|c|}{ Training and Development } \\
\hline Leniency in judgment & \multirow{4}{*}{0.806} & 0.665 & 0.4422 & 0.5578 & \multirow{4}{*}{0.5195} & \multirow{4}{*}{0.721} \\
\hline Differ Evaluation & & 0.807 & 0.6512 & 0.3488 & & \\
\hline Personal Prejudice & & 0.797 & 0.6352 & 0.3648 & & \\
\hline $\begin{array}{l}\text { Uniform Evaluation } \\
\text { Criteria }\end{array}$ & & 0.591 & 0.3493 & 0.6507 & & \\
\hline \multicolumn{7}{|c|}{ Organizational Performance } \\
\hline $\begin{array}{l}\text { Good working } \\
\text { conditions }\end{array}$ & \multirow{4}{*}{0.962} & 0.943 & 0.8892 & 0.1108 & \multirow{4}{*}{0.8637} & \multirow{4}{*}{0.929} \\
\hline $\begin{array}{l}\text { Employee } \\
\text { Performance }\end{array}$ & & 0.965 & 0.9312 & 0.0688 & & \\
\hline $\begin{array}{l}\text { Employee } \\
\text { Satisfaction }\end{array}$ & & 0.934 & 0.8724 & 0.1276 & & \\
\hline Productivity & & 0.873 & 0.7621 & 0.2379 & & \\
\hline \multicolumn{7}{|c|}{ Career Planning and Development } \\
\hline \multirow{4}{*}{$\begin{array}{l}\text { Counseling for future } \\
\text { development } \\
\text { Taking Monitory care } \\
\text { for future } \\
\text { Advanced skill } \\
\text { enhancement } \\
\text { Creating ladders for } \\
\text { future }\end{array}$} & \multirow{4}{*}{0.804} & 0.741 & 0.5491 & 0.4509 & \multirow{4}{*}{0.5305} & \multirow{4}{*}{0.728} \\
\hline & & 0.899 & 0.8082 & 0.1918 & & \\
\hline & & 0.743 & 0.5520 & 0.4480 & & \\
\hline & & 0.461 & 0.2125 & 0.7875 & & \\
\hline \multicolumn{7}{|c|}{ Ethical Dilemma } \\
\hline Organizational ethics & \multirow{4}{*}{0.844} & 0.68 & 0.4624 & 0.5376 & \multirow{4}{*}{0.5828} & \multirow{4}{*}{0.763} \\
\hline Code of Conduct & & 0.791 & 0.6257 & 0.3743 & & \\
\hline employee aspects & & 0.875 & 0.7656 & 0.2344 & & \\
\hline Relational aspects & & 0.691 & 0.4775 & 0.5225 & & \\
\hline
\end{tabular}




\begin{tabular}{|c|c|c|c|c|c|c|}
\hline \multicolumn{7}{|c|}{ Employee Compensations } \\
\hline \multirow{4}{*}{$\begin{array}{l}\text { Pay in Regular } \\
\text { intervals. } \\
\text { Inequality in payment } \\
\text { Inequality in payment } \\
\text { as per norms } \\
\text { Pay as per } \\
\text { Performance }\end{array}$} & \multirow{4}{*}{0.901} & 0.788 & 0.6209 & 0.3791 & \multirow{4}{*}{0.2985} & \multirow{4}{*}{0.546} \\
\hline & & 0.888 & 0.7885 & 0.2115 & & \\
\hline & & 0.885 & 0.7832 & 0.2168 & & \\
\hline & & 0.783 & 0.6131 & 0.3869 & & \\
\hline
\end{tabular}

Hierarchical Regression Analysis:- In the first step (Model 1) all control variables viz., gender, age, educational qualification, salary and span of service were entered. Among the control variables age $(\beta=.183, p<.000)$ followed by salary $(\beta=.381, \mathrm{p}<.000)$ and services $(\beta=.202, \mathrm{p}<.000)$ are significant. The remaining Gender, Education qualification are not significant predictors of employee satisfaction. The control variables model was significant $(\mathrm{F}=65.415, \mathrm{p}<.000)$ explaining $36 \%$ variation at employee satisfaction with the effect of control variable. In step 2 (Model 2) we entered the main variables in regression equation. This direct effects model suggests that the regression coefficients of appraisal $(\beta$ $=.117, \mathrm{p}<.000)$, training $(\beta=.156, \mathrm{p}<.000)$, compensation $(\beta=.246, \mathrm{p}<.000)$, career development $(\beta=-.329, \mathrm{p}<.000)$. Explained $17 \%$ extra variance due to main variables. The model was significant $(\mathrm{F}=65.415, \mathrm{p}<.000 ; \mathrm{R} 2=.530 ; \Delta \mathrm{F}=$ $44.078, \mathrm{p}<.000 ; \Delta \mathrm{R} 2=.148)$ and explained $36 \%$ of variance on employee satisfaction due to interaction variables followed by the total $51 \%$ of cumulative variance due to main variable, which tells that the addition of $15 \%$ of variance generated with the effect of main variable.

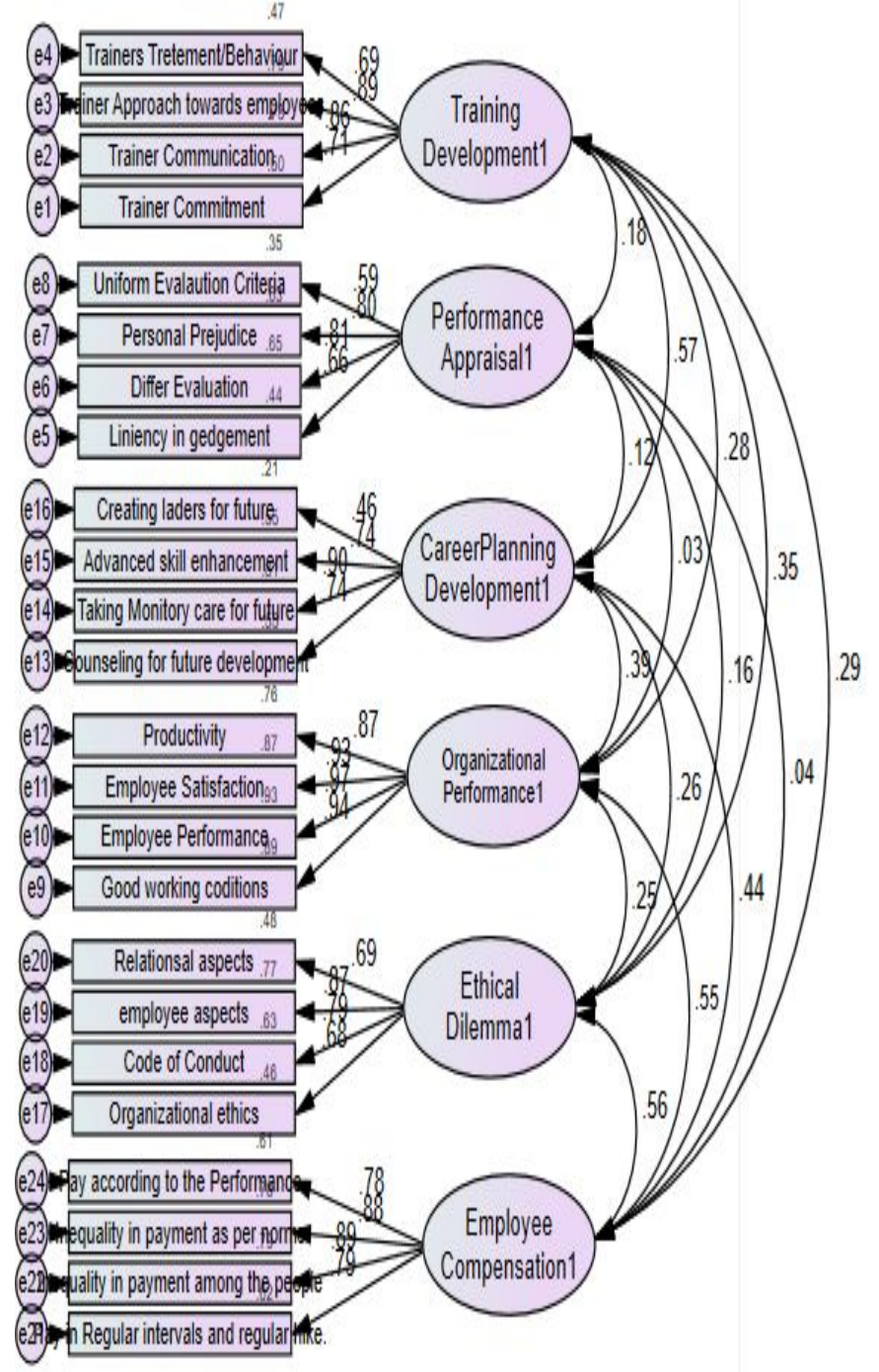

Figure 2: Confirmatory Factor Analysis

Table 3: Results of Hierarchical Regression Analysis

\begin{tabular}{lll}
\hline \multirow{2}{*}{ Dependent Variable } & $\begin{array}{l}\text { Emp.Satisfacti } \\
\text { on }\end{array}$ & $\begin{array}{l}\text { Emp.Satisfacti } \\
\text { on }\end{array}$ \\
\cline { 2 - 3 } & Model 1 & Model 2 \\
\hline Independent & $\begin{array}{l}\text { Control } \\
\text { Variable }\end{array}$ & Main Variable \\
\hline Gender & .005 & -.035 \\
& $(.193 ; .847)$ & $(-1.068 ; .286)$ \\
Age & $.183^{* * *}$ & $.155^{* * *}$ \\
Education & $(4.667 ; .000)$ & $(4.341 ; .000)$ \\
Qualification & -.057 & -.002 \\
Salary & $(-1.196 ; .232)$ & $(-.057 ; .954)$ \\
Service & $.381 * * *$ & $.250^{* * *}$ \\
& $(7.895 ; .000)$ & $(5.629 ; .000)$ \\
& $.202 * * *$ & .119
\end{tabular}




\begin{tabular}{|c|c|c|}
\hline \multirow{2}{*}{\multicolumn{2}{|c|}{ Performance }} & \\
\hline & & $.111 * * *$ \\
\hline \multicolumn{2}{|l|}{ Appraisal } & $(3.704 ; .000)$ \\
\hline \multirow{2}{*}{\multicolumn{2}{|c|}{$\begin{array}{l}\text { Training } \\
\text { Development }\end{array}$}} & .206 \\
\hline & & $(5.284 ; .000)$ \\
\hline \multicolumn{2}{|l|}{$\begin{array}{l}\text { Career Planning \& } \\
\text { development }\end{array}$} & \\
\hline \multicolumn{2}{|l|}{ Employee } & -.034 \\
\hline \multicolumn{2}{|l|}{ Compensation } & $(-1.019 ; .309)$ \\
\hline R2 & .361 & .510 \\
\hline Adjusted R2 & $.3 / 6$ & .522 \\
\hline$\Delta \quad$ R2 (R-Square & .381 & .148 \\
\hline F-Value & $65.415^{* * *}$ & $65.415 * * *$ \\
\hline$\Delta \mathrm{F}$-Value & 6 & 44. \\
\hline & $(5,563)$ & $(9,559)$ \\
\hline \multicolumn{3}{|c|}{$\begin{array}{c}* * * \mathrm{p}<.0001, * * \mathrm{p}<.01,{ }^{*} \mathrm{P}<.05 ; \text { standardized regression } \beta \\
\text { coefficients are reported; } \mathrm{t} \text {-values and } \mathrm{p} \text {-values are in } \\
\text { parentheses }\end{array}$} \\
\hline \multicolumn{3}{|c|}{ 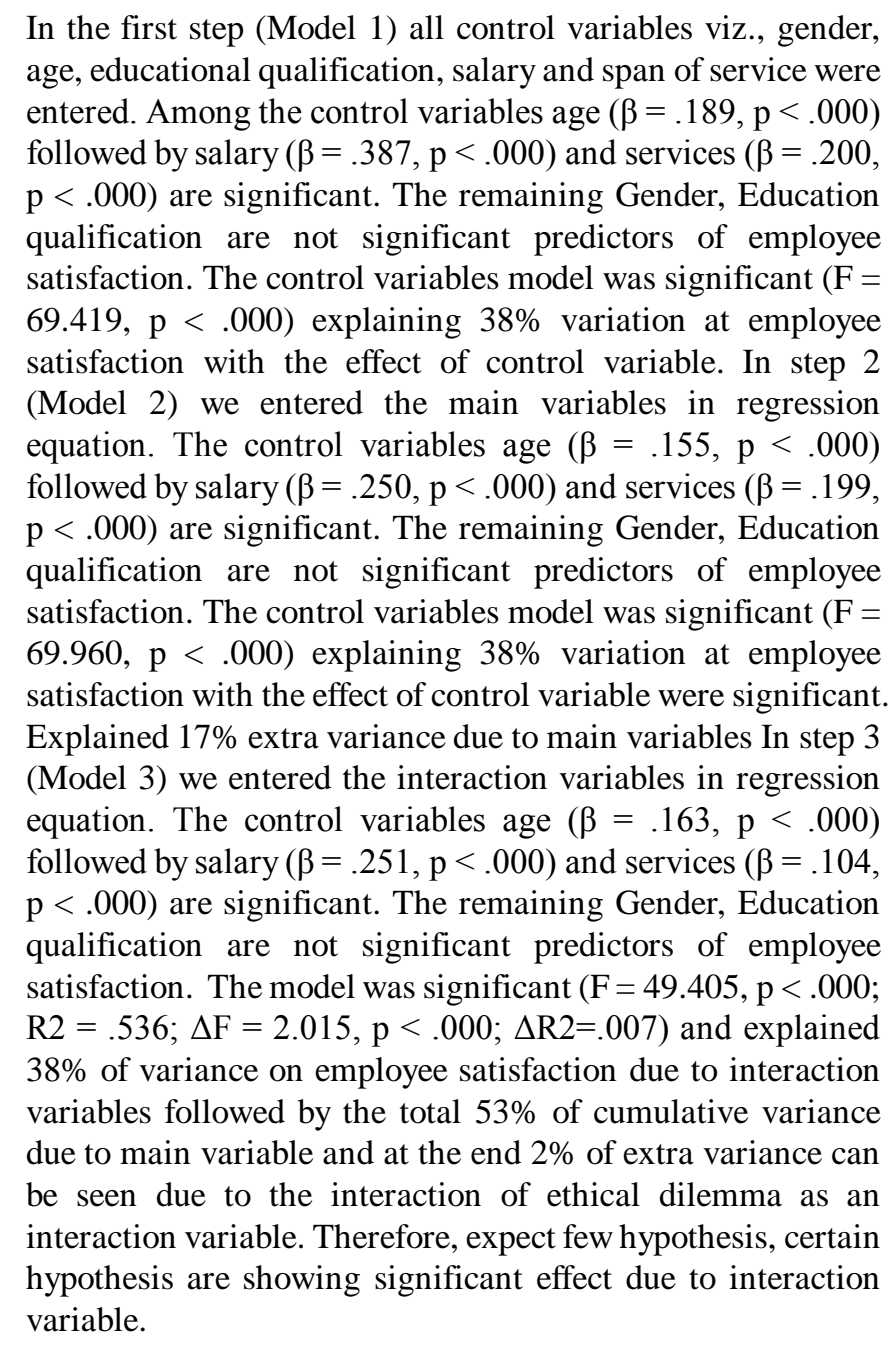 } \\
\hline
\end{tabular}

Table4: Results of Hierarchical Regression Analysis

\begin{tabular}{|c|c|c|c|}
\hline \multirow[t]{2}{*}{ Dependent Variable } & Satisfaction & $\begin{array}{c}\text { Satisfacti } \\
\text { on } \\
\end{array}$ & Satisfaction \\
\hline & Model 1 & Model 2 & Model 3 \\
\hline $\begin{array}{l}\text { Independent } \\
\text { Variable }\end{array}$ & $\begin{array}{l}\text { Control } \\
\text { Variables }\end{array}$ & $\begin{array}{l}\text { Main } \\
\text { Variable }\end{array}$ & $\begin{array}{l}\text { Interaction } \\
\text { Variables }\end{array}$ \\
\hline Gender & $\begin{array}{c}.007 \\
(.193 ; .847)\end{array}$ & $\begin{array}{c}-.035 \\
(-1.068 \\
.286)\end{array}$ & $\begin{array}{c}-.056 \\
(-1.656 ; .098)\end{array}$ \\
\hline Age & $\begin{array}{c}.189^{* * *} \\
(4.667 ; \\
.000)\end{array}$ & $\begin{array}{c}.155 * * * \\
(4.341 ; \\
.000\end{array}$ & $\begin{array}{c}.163 \\
(4.531 ; .000)\end{array}$ \\
\hline $\begin{array}{l}\text { Education } \\
\text { Qualification }\end{array}$ & $\begin{array}{c}-.057 \\
(-1.196 ; \\
.232)\end{array}$ & $\begin{array}{l}-.002 \\
(-.057 \\
.954)\end{array}$ & $\begin{array}{c}.002 \\
(.042 ; .966)\end{array}$ \\
\hline Salary & $\begin{array}{c}.387 * * * \\
(7.895 ; \\
.000)\end{array}$ & $\begin{array}{c}.250 * * * \\
(5.629 \\
.000)\end{array}$ & $\begin{array}{c}.251 \\
(5.660 ; .000)\end{array}$ \\
\hline Service & $\begin{array}{c}.200 * * * \\
(3.616 ; \\
.000)\end{array}$ & $\begin{array}{c}.119 \\
(2.424 \\
.016)\end{array}$ & $\begin{array}{c}.104 \\
(2.120 ; .034)\end{array}$ \\
\hline PA & & $\begin{array}{l}.111 * * * \\
(3.704 ; \\
.000)\end{array}$ & $\begin{array}{c}.065 \\
(.734 ; .463)\end{array}$ \\
\hline TD & & $\begin{array}{l}.206 * * * \\
(5.284 ; \\
.000)\end{array}$ & $\begin{array}{c}-.013 \\
(-.060 ; .952)\end{array}$ \\
\hline CPD & & $\begin{array}{l}.269 * * * \\
(6.632 \\
.000)\end{array}$ & $\begin{array}{c}.550 \\
(2.568 ; .010)\end{array}$ \\
\hline $\mathrm{EC}$ & & $\begin{array}{c}-.034 \\
(-1.019 \\
.309)\end{array}$ & $\begin{array}{c}-.208 \\
(-1.750 ; .081)\end{array}$ \\
\hline PA X ED & & & $\begin{array}{c}.066 \\
(.524 ; .601)\end{array}$ \\
\hline CPD X ED & & & $\begin{array}{c}-.428 \\
(-1.312 ; .190)\end{array}$ \\
\hline $\mathrm{TD} \quad \mathrm{X}$ ED & & & $\begin{array}{c}.285 \\
(.912 ; . .362)\end{array}$ \\
\hline $\mathrm{EC} \quad \mathrm{X}$ ED & & & $\begin{array}{c}.250 \\
(1.294 ; .196)\end{array}$ \\
\hline $\mathrm{R}^{2}$ & .381 & .530 & .556 \\
\hline Adjusted $\mathrm{R}^{2}$ & .376 & .522 & .526 \\
\hline$\Delta \mathrm{R}^{2}$ & .381 & .148 & .007 \\
\hline F-Value & $69.419 * * *$ & $\begin{array}{c}69.960 * * \\
*\end{array}$ & $49.405 * * *$ \\
\hline$\Delta \mathrm{F}$-Value & 69.419 & 44.078 & 2.015 \\
\hline Df & 5,563 & 4,559 & 4,555 \\
\hline
\end{tabular}

$* * * \mathrm{p}<.0001, * * \mathrm{p}<.01, * \mathrm{P}<.05 ;$ standardized regression $\beta-\mathrm{co}$ efficient are reported; $t$-values and $p$-values are in parentheses 


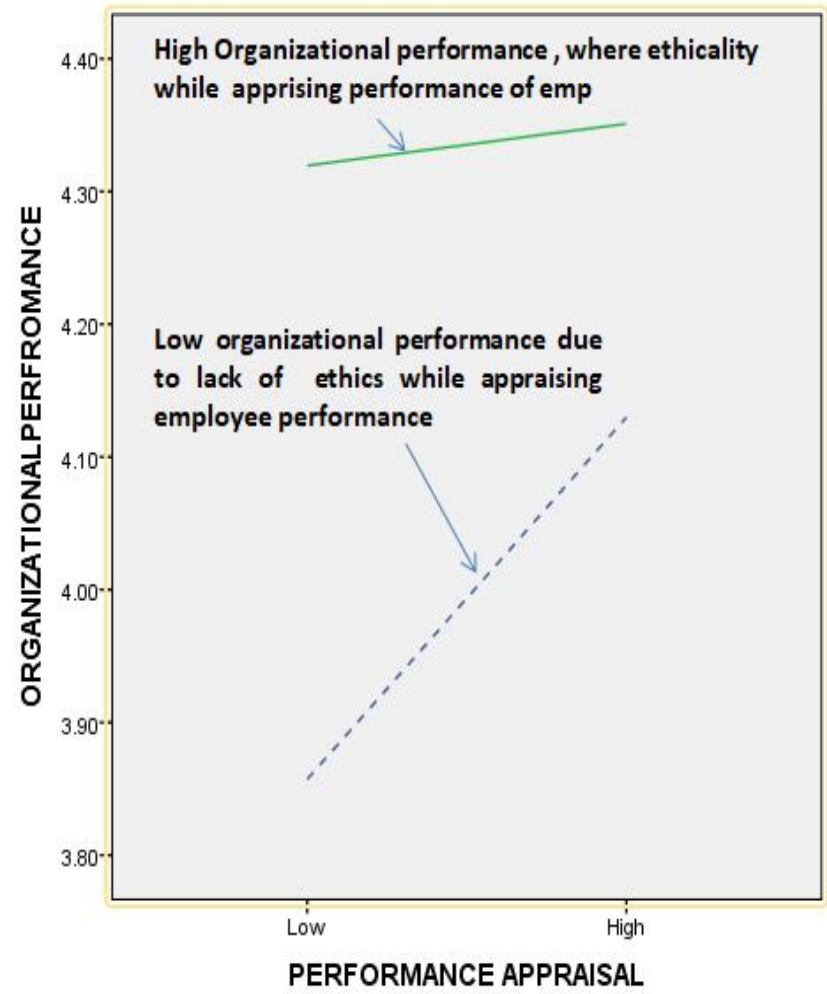

Graph 1: Interaction plot: OP: PA \& ED

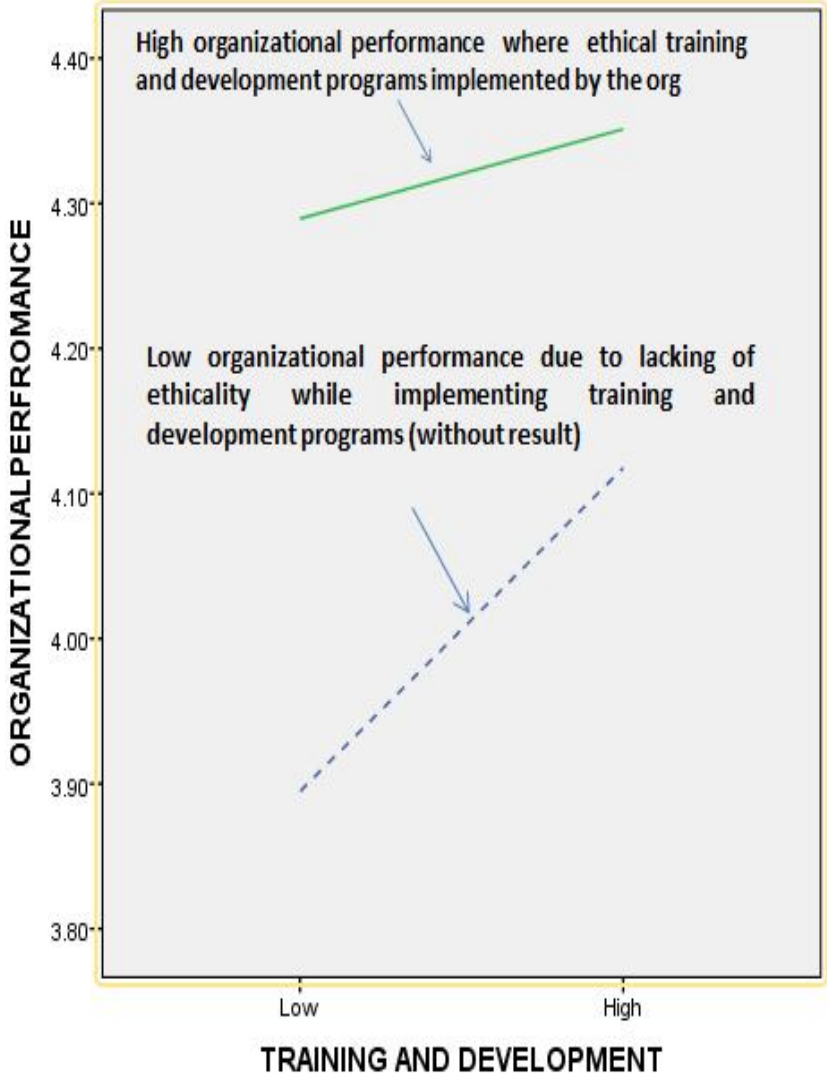

Graph 2: Interaction plot: OP: TD \& ED

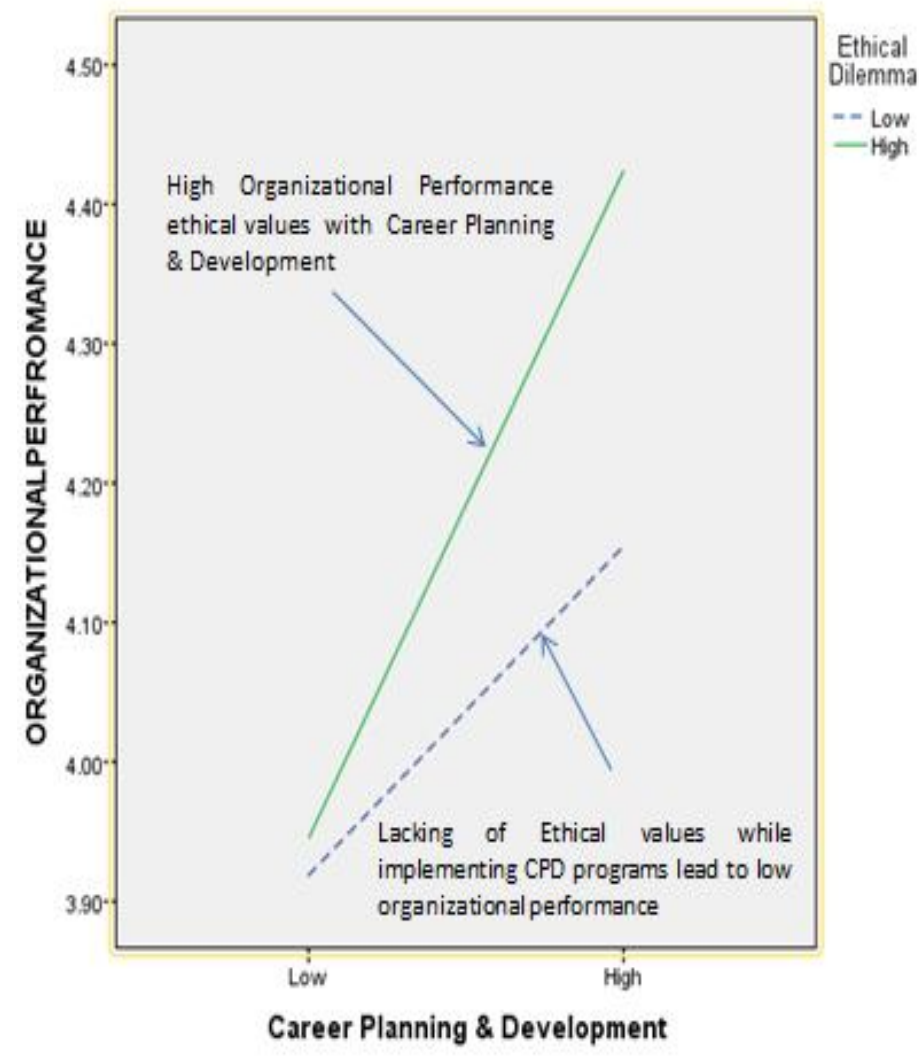

Graph 3: Interaction plot: OP: CPD \& ED ETHICAL DILEMMA

- - Low
- High

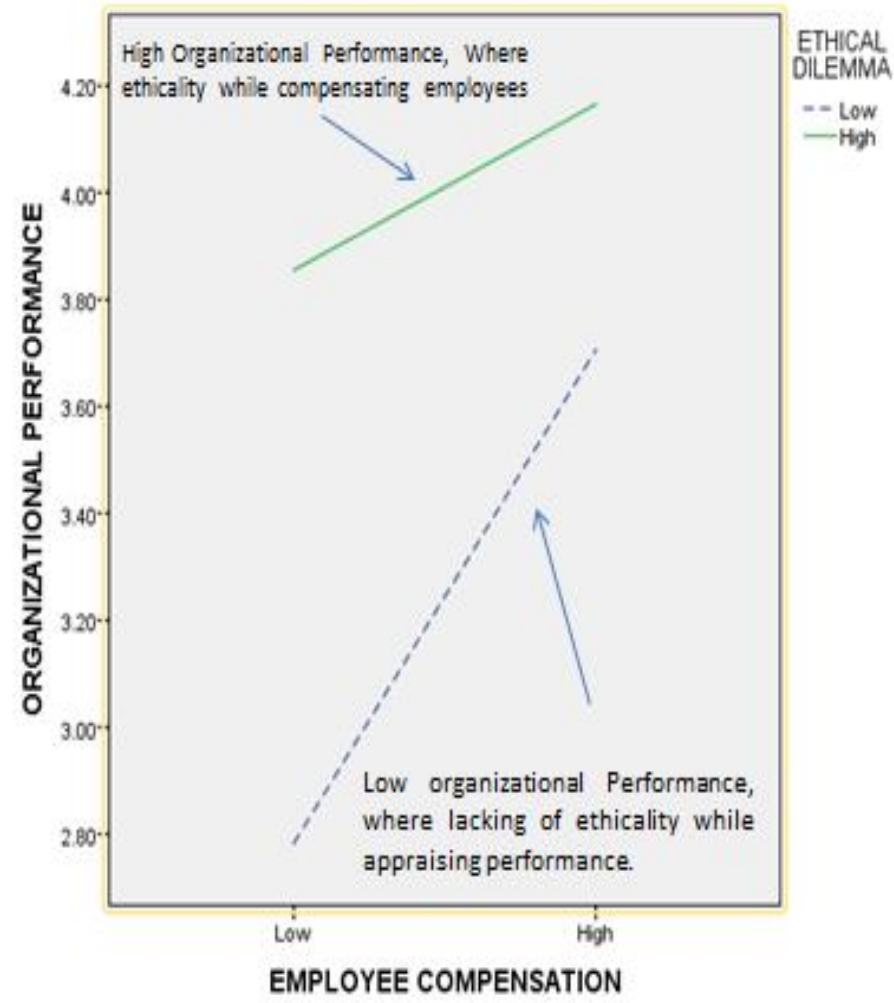

Graph 4: Interaction plot: OP: EC \& ED 


\section{FINDINGS}

- The following control variables like: age $(\beta=.183, \mathrm{p}<$ $.000)$ followed by salary $(\beta=.381, \mathrm{p}<.000)$ and services $(\beta=.202, \mathrm{p}<.000)$ have shown significant positive relationship with the employee performance and organizational performance.

- The control variables model was significant $(\mathrm{F}=69.960$, $\mathrm{p}<.000$ ) explaining 38\% variation at employee satisfaction with the effect of control variable were significant. Explained 17\% extra variance due to main variables. Therefore, it is evident from the research that, the control variables (age, income, educational qualifications) have shown the significant impact on employee performance.

- In the results $2 \%$ variance was observed due to the impact of interaction variable (Ethical values) while appraising employee performance followed by organizational performance.

- The moderating variable (Ethical values) has shown the significant positive, impact with respect to organizational performance and employee performance appraisal.

- The moderating variable (Ethical values) has shown significant positive impact with respect to organizational performance and employee career development planning.

- The moderating variable has shown significant positive relationship with the employee compensation and organizational performance.

\section{CONCLUSION}

Therefore, it can be conclude that, the ethical values will influence the organizational performance in such a manner that, greater the value of ethics which leads to greater performance can be expected in employee performance which leads to organizational performance. The performance appraisal, training and development, career planning and development and employee compensations are major indicators for the organizational performance and even control variables like: age, gender, income and educational qualifications of the respondents have shown the significant positive relationship with the employee performance.

\section{REFERENCES}

1. Dr. Rajkumar Salgar and Anandan Priya. Human Resource Development Practices - A Study With Special Reference To Kmf, Karnataka. International Journal Of Innovative Research In Technology, Vol.5 , pp.156-164, August 2019.

2. Srinibash Dash and Uma Charan Pati. The effect of HRD practices for high- performance work systems: An empirical study on IT industries in India. Espacios, Vol.3, , P.15, March.2018.

3. Thyagaraju N. (2017). Human Resources Development
(Hrd) Practices In India. International Journal of Recent Scientific Research, Vol.8. , pp2474-22477, 2017

4. S. ANURADHA, and M. S. PRASANTH. Employees' perception towards HRD practices among select public sector banks in Puducherry. Indian Journal of Applied Research, Vol.6, pp 249-252, 2016

5. Teju kujur and Mushtaq Ahmad Shah. Innovative Human Resource Practices In Indian Banks: A Study From HR Manager's Perspective. IVandana Saxena Int. Journal of Engineering Research and Application, Vol.6(3), pp.40-48, 2016

6. Gutta Balakrishna and Dr. Sucharitha Devarapu.. Hrd Practices For Developing Growth Rate In Service Sector-India. Anveshana International Journal Research In Regional Studies, Law, Social Sciences, Journalism And Management, Vol.1(3), pp.39-46, 2016.

7. Homera A Durani, Krupa U Trivedi, and Aqsa A Durani. Innovative HR Strategic Practices of Indian and Foreign MNCs. Original Research Journal of Management Research and Analysis, Vol.2, pp173-176, 2015.

8. Trehan, S., and Setia, K. (2014). Human Resource Management Practices and Organizational Performance: An Indian Perspective. Global Journal of Finance and Management, Vol.6, pp.789-796, 2014.

9. Bonavia, T., and Marin-Garcia, Integrating human resource management into lean production and their impact on organizational performance. International Journal of Manpower, Vol.32 (8), pp. 923-938, 2011.

10. Akhtar, S., Ding, D. Z. and Ge, G. L. Strategic HRM practices and their impact on company performance in Chinese enterprises. Human resource management, Vol.1, pp.15-32, 2008

https://doi.org/10.1002/hrm.20195

11. Vanhala, S., and Stavrou, E. Human resource management practices and the HRM-performance link in public and private sector organizations in three Western societal clusters. Baltic Journal of Management, Vol.8(4), pp.416-437, 2013

https://doi.org/10.1108/BJM-12-2012-0115

12. Martin, K. D., and Cullen, J. B. (2006). Continuities and extensions of ethical climate theory: A meta-analytic review. Journal of business ethics, Vol.69(2), pp.175-194, 2006.

13. Islam, M. Z. and Siengthai, S. (2010). Human resource management practices and firm performance improvement in Dhaka Export Processing Zone (DEPZ). Research and Practice in Human Resource Management, Vol.18 (1), pp.60-77, 2010.

14. Joarder, M. H. R. and Ashraf, M. A. Work Satisfaction andd Employee Turnover Intentions: An Empirical Study. East West Journal of Business \& Social studies, Vol. 3, pp.216-221, 2012.

15. John Louis D. Mercaral. Prediction of Employees Lateness Determinants using Machine Learning Algorithms, International Journal of Advanced Trends in Computer Science and Engineering, Vol.9, 
pp.779-783,2020.

https://doi.org/10.30534/ijatcse/2020/111912020.

16. Riyanto Jayadi. Employee Performance Prediction using Naïve Baye, International Journal of Advanced Trends in Computer Science and Engineering, Vol.8, pp.3031-3035, 2019 , https://doi.org/10.30534/ijatcse/2019/59862019

17. Gunawan Wang. The Influence of Social Media and Knowledge Management to Improve Employees Creativity, International Journal of Advanced Trends in Computer Science and Engineering, Vol.8, pp.1927-1936, 2019, https://doi.org/10.30534/ijatcse/2019/17852019

18. Nunnally J. Psychometric theory. McGraw-Hill, New York, pp.267-268, 1978

19. Kaiser, H.F. an index of factorial simplicity, Psychometrics, 39, pp. 31-36, 1974. https://doi.org/10.1007/BF02291575

20. Hair J, Black W, Babin B, Anderson R and Tatham R Multivariate data analysis, 7 th edn. Pearson Prentice Hall, Upper Saddle River, 2010.

21. Browne, M.W. and Cudeck, R. Alternative ways of assessing model fit, in Bollen, K.A. and Long J.S.(Eds), Testing of structural equation models, Sage, Newbury Park, CA, pp.136-162, 1993.

22. Jöreskog K and Sörbom D LISREL, Scientific Software International, Chicago, Vol.8, 1993.

23. Byrne B Structural equation modeling with AMOS. Rutledge, Taylor \& Francis Group, New York, 2010.

24. Fornell C and Larcker D (1981) Evaluating structural equation models with unobservable variables and measurement error. J Mark Res Vol.18, 1981. https://doi.org/10.1177/002224378101800313

25. Cole, D. A. Utility of confirmatory factor analysis in test validation research. Journal of counseling and Clinical Psychology, Vol.2, pp55-58, 1987.

https://doi.org/10.1037/0022-006X.55.4.584 